\title{
Transatlantica
}

Revue d'études américaines. American Studies Journal

\section{Alan C. Braddock and Karl Kusserow, Nature's Nation: American Art and Environment}

\section{Carolin Görgen}

\section{(2) OpenEdition}

\section{Journals}

Electronic version

URL: https://journals.openedition.org/transatlantica/15207

DOI: 10.4000/transatlantica. 15207

ISSN: 1765-2766

\section{Publisher}

Association française d'Etudes Américaines (AFEA)

\section{Electronic reference}

Carolin Görgen, "Alan C. Braddock and Karl Kusserow, Nature's Nation: American Art and Environment", Transatlantica [Online], 1 | 2020, Online since 01 December 2020, connection on 31 January 2023. URL http://journals.openedition.org/transatlantica/15207 ; DOI: https://doi.org/10.4000/transatlantica. 15207

This text was automatically generated on 31 January 2023.

\section{(†)

Creative Commons - Attribution-NonCommercial-NoDerivatives 4.0 International - CC BY-NC-ND 4.0 https://creativecommons.org/licenses/by-nc-nd/4.0/ 


\title{
Alan C. Braddock and Karl Kusserow, Nature's Nation: American Art and Environment
}

\author{
Carolin Görgen
}

\section{REFERENCES}

Alan C. Braddock \& Karl Kusserow, Nature's Nation. American Art and Environment, New Haven, Yale University Press, distributed for the Princeton University Art Museum, 2018, 448 pages, 326 color + b/w illustrations, ISBN-13: 978-0300237009, \$65

1 At first sight, an ecocritical study of American art entitled "Nature's Nation" may call to mind the lavish canvasses of the Hudson River School or Ansel Adams's pristine Yosemite prints. Yet what to make of a high chest of drawers from the 1760s, a woven robe by a Tlingat artist from Alaska, or Alexander Gardner's Civil War photographs and their ecological underpinnings? The monumental exhibition catalogue Nature's Nation unites these (and many more) objects in an eye-opening, unapologetically interdisciplinary study that multiplies critical perspectives on American art in a twenty-first century framework.

Published for the traveling exhibit at Princeton University Art Museum, Peabody Essex Museum, and the Crystal Bridges Museum of American Art, the 450-page catalogue, with its more than 300 illustrations, is not merely a portrayal of the exhibition-it may well become the first manual on "American art and environment" for students and scholars alike. With contributions from art historians, curators, humanities scholars, climate justice activists, and contemporary artists, the catalogue covers four centuries in nineteen essays, and sets a virtuosic example of doing ecocritical art history, critical apparatus and all. While Cheryll Glotflety and Lawrence Buell have paved the now welltrodden path of literary ecocriticism from the 1990s, Nature's Nation amplifies the voices of the ecocritical cast, including scholars of urbanization, political theorists, and 
indigenous printmakers. The echo of Timothy Morton's Ecological Thought (2010)affirming that "[e]cology permeates all forms" (Morton, 11)-thus resonates throughout the volume. In the making since 2011, the exhibition project is the fruit of the collaboration of Alan Braddock, Associate Professor of American Studies and Art History at William \& Mary, and Princeton University Art Museum curator Karl Kusserow, both of whom have made substantial contributions to the field. ${ }^{1}$

Their introduction sets the tone for the vast study to follow, asserting that

art has always embodied ecological conditions, both materially and conceptually, whether its makers recognized it or not, for their work cannot help but bear traces of some connection with the earth, its ecosystems, and its many inhabitants human and nonhuman. (13)

Yet, instead of supporting the seemingly celebratory tenor of a nation rooted in nature, the authors adopt a critical reading of what would be considered "natural" and "national" in the Euro-American colonial narrative. This also includes the term "Anthropocene"-the designation of the geological era in which human impact on the Earth becomes tangible. Although hotly contested in recent years, the authors choose to uphold it as it illustrates the impact of a country that, according to them, "has done more to create the Anthropocene than any other," especially through its devastating ecological footprint (12). With this critically conscious use of terms, Braddock and Kusserow walk a tightrope, quite masterfully, between defining the fruitful terrain of ecocriticism in the U.S. and avoiding decade-old tropes of exceptionalism.

The authors introduce their analysis with two classic examples of nineteenth-century landscape painting-Thomas Moran's Yellowstone and Albert Bierstadt's Yosemite canvases. Instead of repeating familiar tropes of national imagination through "wild" landscapes, they draw attention to the Euro-American construction of aesthetically pleasing sites, the denial of indigenous knowledge in tending to the land, and vast infrastructural transformations to facilitate access for wealthy (read white) touristsall of which are embedded in the paintings. While still acknowledging the impact of this late nineteenth-century visual culture on the American conservation movement, the authors shed light on recent artistic treatments of such conflicted landscapes. They juxtapose Bierstadt, Moran, and the canon of male landscape painters with contemporary works by female and/or indigenous artists, most notably Valerie Hegarty's Fallen Bierstadt (2007)-a mixed medium installation of an eroding canvaswhich adorns the cover of the catalogue (Fig. 1). 


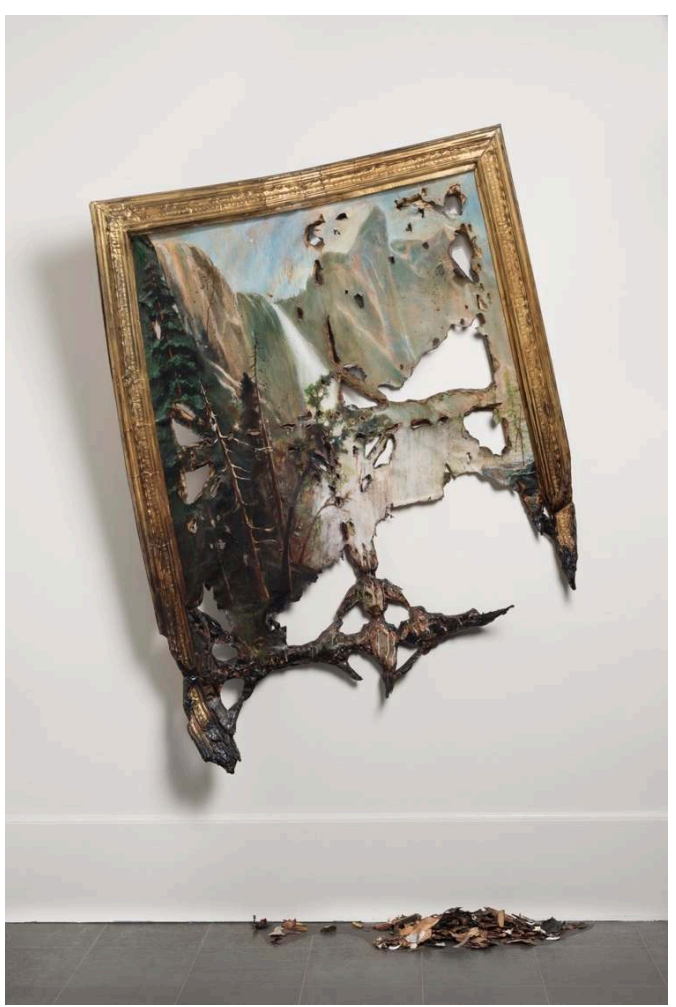

Valerie Hegarty (American, born 1967), Fallen Bierstadt, 2007. Foamcore, paint, paper, glue, gel medium, canvas, wire, wood, 2008.9a Wall piece: $177.8 \times 127 \times 42.5 \mathrm{~cm}$. Brooklyn Museum, Gift of Campari, USA, 2008.9a-b.

(c) Valerie Hegarty

This uncovering of dominant assumptions about the environment is further exemplified in an alternative North American map by Jaune Quick-to-See Smith (Confederated Salish and Kootenai Nation) who depicts tribal territories and species across national borders. In pairing Smith's collage The Browning of America (2000) with nineteenth-century canvases, the authors embrace not only the diversity of lived environmental experience, but also introduce shifting academic approaches-thus announcing the decolonial and ecofeminist readings to come. Through this focus on marginalized histories and practices, on overlooked regions and materialities, and on unexpected combinations artworks, Braddock and Kusserow shed light on the ecological tissue interwoven with American art.

Divided into three parts, the catalogue then covers "Colonization and Empire," "Industrialization and Conservation," and "Ecology and Environmentalism," roughly following a chronology from the eighteenth to the twenty-first century. As recounting both the breadth of illustrations and the depth of analysis seems an impossible task, this review presents a selection of examples from each section that appear particularly enriching.

7 The first part, "Colonization and Empire," tackles the notion of "natural order"epitomized in the Great Chain of Being-alongside an emerging expansionist agenda and territorial conflict around the 1800s. Braddock's and Kusserow's essays examine western Anthropocentrism, which placed humans at the top of a predetermined hierarchy, and its derivation from Plato and Aristotle, its perpetuation across Europe by scholars like Carl Linnaeus, along with its exportation through colonial conquest. 
The most fervent disciple of Linnaean taxonomy and its natural classification in the U.S. was Charles Willson Peale. Braddock demonstrates how Peale's hierarchical display of American politicians, scientists, and natural history specimens in his Philadelphia museum-mounted amid political turmoil in the early republic-served as prime instructor of an imposed order, despite its public accessibility. These beliefs were solidified in the display of a mastodon whose bones had been excavated in New York under Peale's patronage, with help from the U.S. Army in 1801. Amid vivid debates of "naturalistic nationalism" (55) between the French Comte de Buffon and Thomas Jefferson, the mastodon seemed to prove American dominance of nature. Yet, its nonexistence in the contemporary world-its having gone extinct, as declared by French naturalist George Cuvier-subverted the 'natural order' aspired to by white American elites. In a compelling comparison, Braddock links these unsettling scientific discoveries to John James Audubon's 1830s series The Birds of America, which reproduced life-size specimens in their habitat. These detailed depictions of violent hunting scenes, alongside commentary on the rapid disappearance of species in the Southeast, bear relevance today. In a composition reminiscent of the grand landscape tradition, contemporary artist Walton Ford shows a dying parakeet among its peers, all eerily resembling Audubon's specimens (Fig. 2).

Figure 2

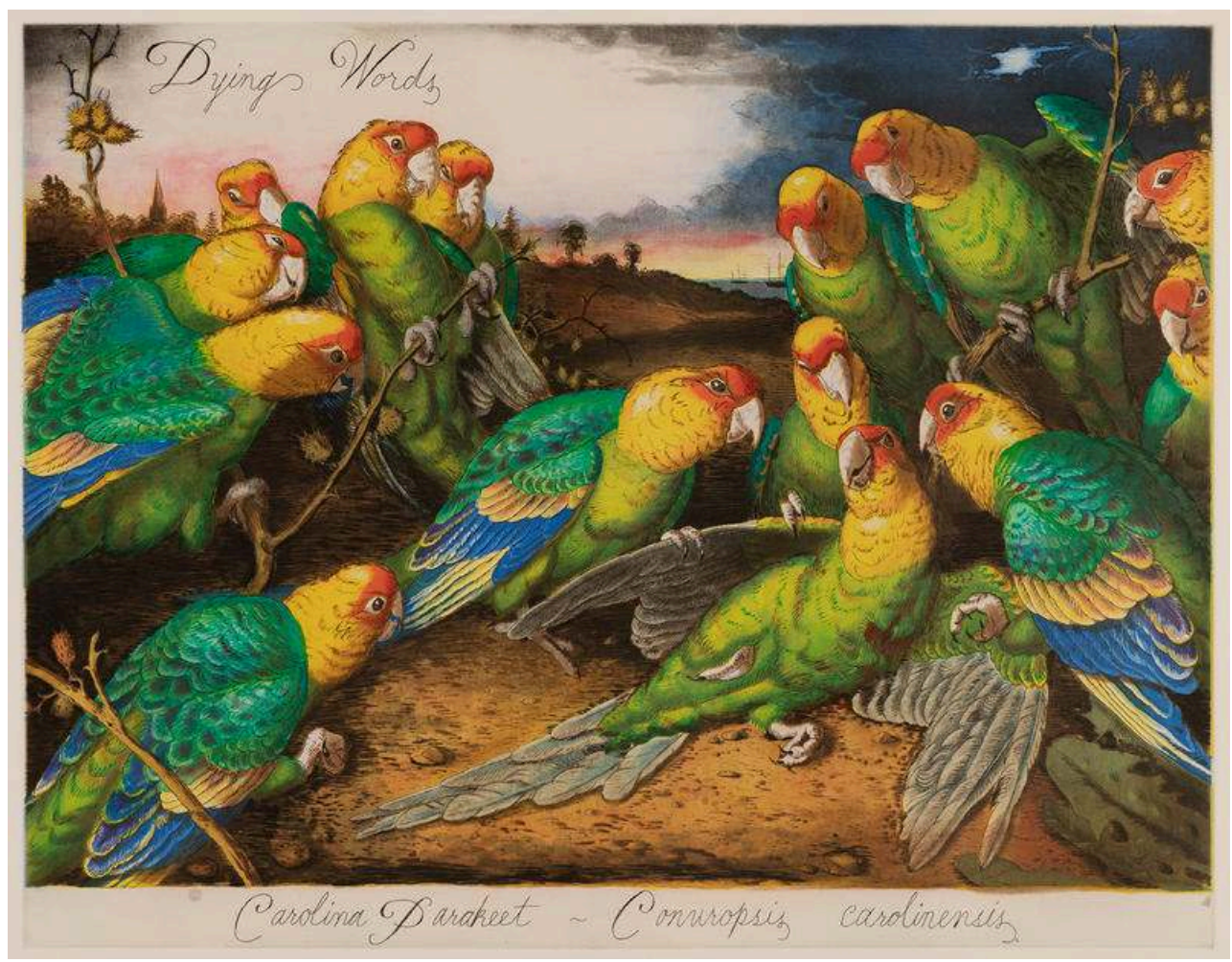

Walton Ford (American, born 1960), Dying Words, 2005. Etching and aquatint on paper, 35.6 × 45.7 $\mathrm{cm}$.

Gift of Ethel Thomson Runion. McNay Art Museum, San Antonio.

8 The ordering impulse is further explored in two essays by Kusserow on the evolution of landscape views from the early colonial era to the 1800s. From representations of Carolina Algonquians in the sixteenth century to family portraits of wealthy Maryland families two hundred years later, the author retraces the effort to domesticate an 
unknown environment. Classic elements resurface in the colonial-era portraits by Justus Engelhardt Kühn, notably in the shape of imaginary backgrounds with carefully laid out gardens and forests, flowers and pets. The aesthetic change that came about during the Enlightenment with a more explicit embrace of "wild" aspects is documented in Ralph Earle's and William Winstanley's works of the 1790s that show a harmonious interplay of settlement and resource abundance. Kusserow explains how the latter's canvases "picturing an American environment made accessible and domesticated through the controlling conventions of the picturesque" particularly pleased George Washington, who displayed them at his Mount Vernon Estate, thus making it "the first gallery of American landscape art" (84). More importantly, the author connects these dominating visions to the enslaved people at Mount Vernon plantation, erased in the many Washington family portraits by Benjamin Latrobe and others. Juxtaposing the reliance on enslaved labor with its erasure in most eighteenthand nineteenth-century visual culture, Kusserow emphasizes the stark contrast of lived environmental experience.

9 Another chapter is dedicated to the Hudson River School, and more specifically Thomas Cole's grappling with Jacksonian Era ideals of progress, as well as Frederic Edwin Church's following of Humboldt travels in South America. The discussion of dramatic landscapes is completed with Albert Bierstadt's visual promotion of a promising West awaiting settlement which yet again presented the removal of indigenous peoples as part of a "natural" order. Kusserow highlights the longevity of such dominant visions and protest against them in the work of contemporary artist Alan Michelson (Mohawk). The latter reproduced a small-sized picturesque cabin, present in many canvases of the Hudson River School, constructed out of paper with the imprint of the Treaty of Fort Wayne on it-a treaty that expulsed Native Americans from a vast portion of the Indiana Territory.

10 These chronologically and thematically coherent chapters present a thoroughgoing analysis of a contested landscape tradition. They are followed by several short case studies that add thought-provoking details. An interview by the editors with Mark Dion displays criticism of the Linnaean scale of nature in contemporary art, while art historian Jeffrey Richmond-Moll examines nineteenth-century food production and consumption as depicted in Raphaelle Peale's still lives of meat. Miranda Belarde-Lewis (Zuni/Tlingit) explains how weaving practices by Chilkat communities in Alaska integrate materials drawn from the land to produce ceremonial objects. Her discussion of a Chilkat robe showing a killer whale, made from goat wool, cedar bark, and vegetal dyes, again exemplifies indigenous conceptions of belonging to the environment rather than possessing it. This material dimension is further analyzed by Laura Turner Igoe who retraces "the political ecology of creative matter" (162). Her analysis of an eighteenth-century high chest of drawers, made of mahogany and brass, places an antique luxury object within a long history of deforestation and enslaved labor in the Caribbean, and health hazards in the British Midlands. Her argument against an "environmental-historical amnesia about the physical stuff of artworks" (140) is particularly powerful as it urges readers to reconsider the itineraries of materials as they are transformed into cultural and commercial goods.

11 The second part, "Industrialization and Conservation," expands the discussion to the nineteenth century by questioning the notion of progress alongside an increasing environmental awareness in American society. In a profusely illustrated essay, 
Braddock documents how urbanization, railroad, mining, farming, and domestic warfare transformed both the lived environment and ways of depicting it. Through paintings by Sanford Robinson Gifford and photographs by Matthew Brady, the author demonstrates the Civil War's impact on humans and non-human lifeforms. He draws a compelling comparison between Winslow Homer's equivalency of bodies and soils ravaged by war, and Timothy O'Sullivan's use of "religious-agricultural tropes" (211) in his Harvest of Death depicting dead soldiers whose blood inundates a wheat field at Gettysburg (Fig. 3).

Figure 3

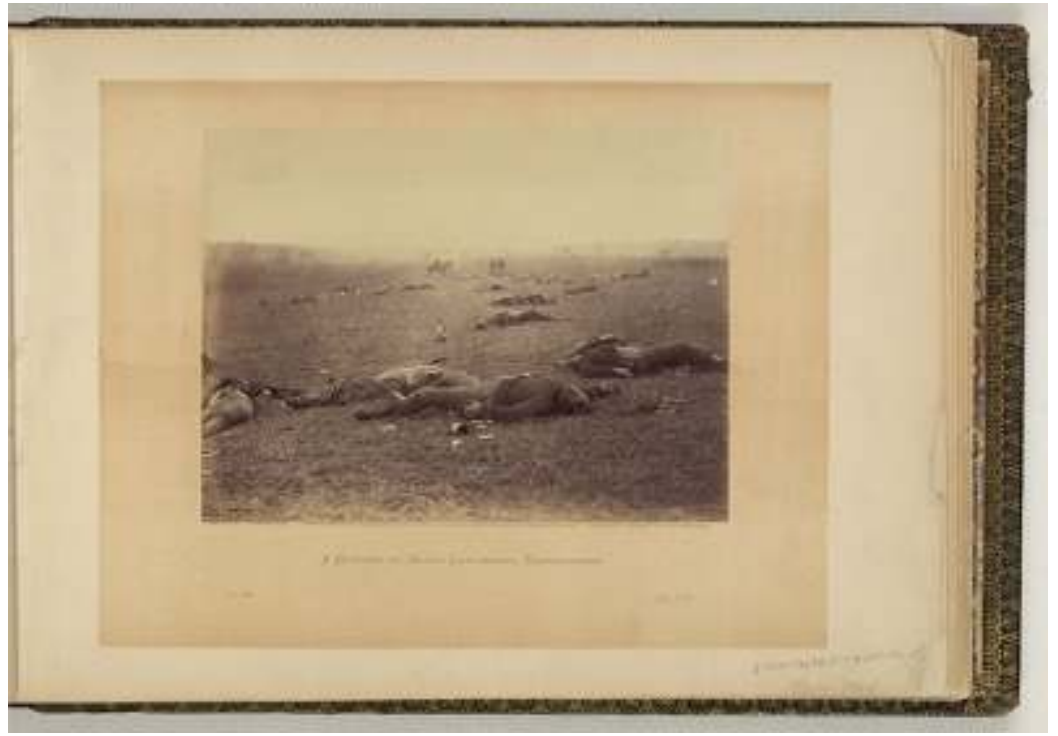

Timothy H. O'Sullivan (American, born Ireland, 1840-1882) and Alexander Gardner (American, born Scotland, 1821-1882), A Harvest of Death, Gettysburg, Pennsylvania / negative by T.H. O'Sullivan; positive by A. Gardner. Illus. in: Gardner's photographic sketch book of the war / Alexander Gardner. Washington, D.C. : Philp \& Solomons, [c1866], v. 1, no. 36. Library of Congress, Washington, D.C., Prints \& Photographs Division.

After a thoughtful analysis of enslaved African-Americans' reliance on environmental knowledge for escape, notably through stellar constellations inscribed on pottery, the ecological matter at the heart of the conflict-cotton-is discussed. Cotton production emerges here as an aesthetic subject, as an exhausting task, and as a catalyst of deforestation. Moving up North, Braddock then turns to the ecological imprint of urbanization in New York City. He explores the large-scale removal of immigrant and African-American neighborhoods and their transformation into an artificial urban recovery space that would become Central Park. In a noteworthy contrast, Braddock points out that the clearing of the future park site required more gunpowder than what was used at the Battle of Gettysburg - not to mention the massive import of soil, trees, and plants. The picturesque aspect of the park, described as particularly beneficial to its visitors, echoes the aesthetic vistas championed in Yosemite paintings of the same period.

13 Another essay by Braddock then focuses on the relationship between patriotic sentiment, indigenous resistance, and the near-extermination of the U.S. bison population in the nineteenth century. The simultaneous dislocation of indigenous populations and the removal of bison herds is exemplified in the paintings of George 
Catlin, who envisioned both "as part of the same tourist spectacle" (251). The author accordingly argues that Catlin's images of dying bison cannot be read as ecologically critical depictions, but instead, must be seen as part of a dominant Euro-American settler narrative that followed yet again a hierarchical notion of "nature." Paintings and vases accompanying the 1876 centennial celebrations, which perpetuated the bison as national icon, are discussed alongside photographs that document the deliberate extermination of buffalo herds to weaken Native communities. A photograph, which shows a massive pile of bones for subsequent processing, must be understood in the context of the Wounded Knee Massacre of 1890, perpetrated by the U.S. Army to contain indigenous rituals to "dance back the buffalo" (259), as for example the Ghost Dance (Fig. 4).

Figure 4

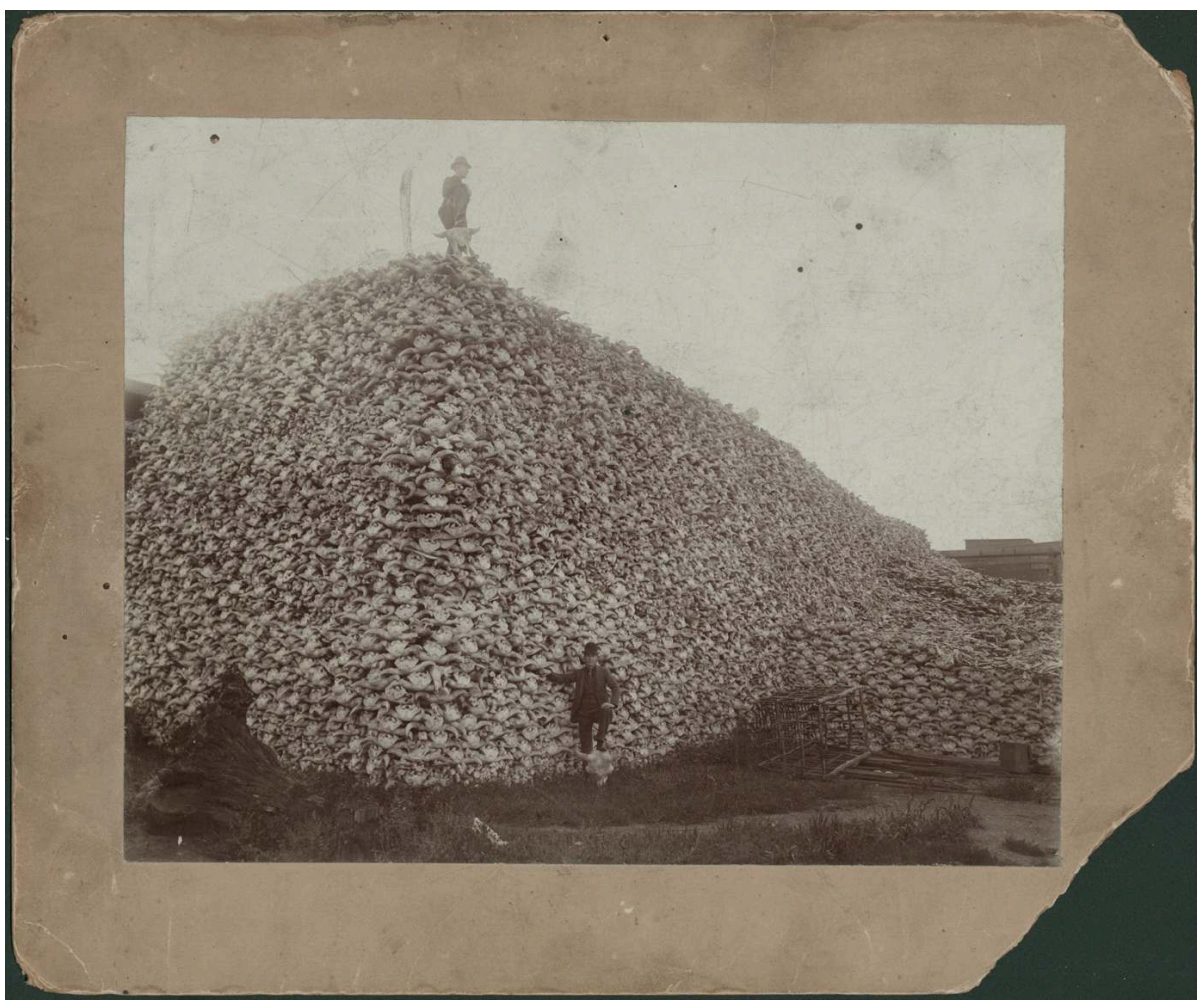

Unidentified photographer, Men Standing with Pile of Buffalo Skulls, Michigan Carbon Works, 1892. Photographic print mounted on mat board.

Braddock contrasts these colonizing exterminations with indigenous objects of the period, more specifically buffalo skin robes that carried spiritual meaning, made by Lakota women and Mandan people of the Great Plains. Moving beyond the turning point of Wounded Knee, the author then analyzes contemporary Native American art linking human and non-human perspectives, for example Layli Long Soldier's (Oglala Lakota) installations that affirm "[a] body beneath a robe means I am human I am dependent" (261).

The collection of short essays, which close the second part, strongly resonates with these two chapters. Rachel Z. DeLue examines Homer Dodge Martin's mining scenes of the 1860s and their links to early ecological research undertaken by geologist Ebenezer Emmons. Similarly, Kimai Shahi studies Martin Johnson Heade's canvases of salt 
marshes and his awareness of interconnected wetlands, labor, and meteorological conditions. In another contribution, influential eco-critic Timothy Morton ponders on the terms used to describe human-made impact and contends that "[t]he Anthropocene is nature in its toxic nightmare form" (269). While these short pieces echo Braddock's chapter on industrial landscapes, a contribution by Jaune Quick-to-See Smith on her engagement with the environment, racism, and immigration refers back to ceremonies like the Ghost Dance, which the artist researched in a series of paintings. Perhaps the most powerful piece in this section comes from Anne McClintock, who proposes the notion of "ghostscape" to understand how the U.S. continues to erase the "foundational violences" inflicted on the indigenous environment (273). The author retraces erasures of settler brutality toward Native peoples: from Edward Curtis' prints that eliminated modern aspects of indigenous life to "an alchemy of erasure-ethnic cleansing at the level of the image erasing ethnic cleansing at the level of history" (279). In an analytical tour de force, McClintock links the ghostscapes of nineteenth-century genocide with the omnipresence of indigenous names in today's U.S. military-all the way to the (later canceled) plan of naming Osama Bin Laden's assassination "Operation Geronimo." Her analysis of imperialism and its attempted erasures provides a meaningful, decolonial postscript to discussions of nineteenth-century environmentalism.

The third and last part, "Ecology and Environmentalism," engages with the ethical dimension of twentieth- and twenty-first-century art. The first chapter "Vital Forms: Modernist Biocentrism" is remarkable in that it filters ecocritical elements out of wellknown twentieth-century visual culture. Predictable works, like Alexandre Hogue's Dust Bowl paintings or Dorothea Lange's portraits for the Farm Security Administration, exemplify artists' reactions to changing environmental conditions. They uphold yet again, as in Lange's case, the myth of a "pioneer farmer"-which had de facto started the drought. Readers also re-encounter Jacob Lawrence's Migration Series, which documents how both the degrading Southern agriculture with insectinfested cotton crops and the urban ecology of the North, prone to tuberculosis, exposed African-Americans to harmful environments.

Reversing the hierarchical model of Western art, Braddock then analyzes what has been termed the "Biocentric approach" (344) of Jackson Pollock: the painter's desire for "decentering humanism" and discarding orderly modes of seeing. The author recognizes a similar aspiration in the photographs of Eliot Porter who deliberately focused on ordinary observations, like leaves in a pond, as opposed to the bombastic glaciers of his photographer- and Sierra Club colleague Ansel Adams. Yet still, as Braddock argues (echoing McClintock), Porter's prints erase the contested past of the 'pristine' landscapes that the Sierra Club sought to preserve.

In the second chapter, "American Art and Planetary Ecology," Braddock and Kusserow further address the increasing environmental awareness of American society during the second half of the twentieth century. In this period of oil spills and pesticide scandals, Rachel Carson published the seminal Silent Spring (1962) and the Nixon Administration created the Environmental Protection Agency (1970).

Next to contextual analyses of Robert Rauschenberg's Earth Day poster or Land Art installations like Robert Smithson's Spiral Jetty, the authors insist on African-American perspectives on environmental injustice. In the lingering cotton plants of Aaron Douglas's Song of the Towers (1966), or in Hughie-Lee Smith's portrait of a destitute Slum Lad (ca. 1960), they read the structural inequality of African-American environmental 
experience, faced with exploitation in the South and urban decay in the North. In this last essay, the authors also come full circle on the phenomenon of mass extinction in recent decades, notably by looking at Andy Warhol's rendering of endangered birds, echoing John James Audubon's Whooping Crane, used for the book Vanishing Animals which Warhol co-edited-thus excavating an ecocritical awareness even in pop-art screen prints.

The third part closes with three short pieces that expand the environmental justice component. Photography scholar Robin Kelsey questions representations of the American landscape-like fine-art prints of national parks-by drawing attention to the massive infrastructure behind this image production. Of particular interest to photohistorians is his connection between the environmental message of practitioners like Ansel Adams and his collaboration with Eastman Kodak-one of "the top corporate polluters in the United States" whose chemicals have contaminated water systems in upstate New York for decades (395). Through this change in perspective, relying on research by Richard Maxwell and others, ${ }^{2}$ Kelsey draws attention to the massive quantities of iron, silver, and rare earths that have been extracted over one-and-a-half centuries to sustain a photographic industry largely concerned with "landscapes." The following piece by Rob Nixon proposes a case study of artistic responses to environmental catastrophes in island geographies: nuclear bomb tests at Bikini Atoll on the Marshall Islands in 1946, the military test site on the Puerto Rican Island of Vieques in use for over six decades, and the Great Pacific Garbage Patch-a trash vortex just below the surface of the sea. A site-specific project at Vieques, by artists Jennifer Allora and Guillermo Calzadilla, integrates both island ecologies and power struggles: Protesters wore custom-made shoe soles that left messages of resistance on the sand at a US Navy Base. These ephemeral footprints (mirroring the military's lasting carbon footprint) affirmed the presence of island inhabitants, while their being washed away by the sea suggested the eventual ephemerality of military power. This selection resonates with Nixon's earlier concept of "slow violence"-environmental damage that slowly, and often imperceptibly, eats away at poor communities. ${ }^{3}$

Questioning geopolitics and power structures is at the heart of the last essay, by Fonna Forman and Teddy Cruz, whose Cross-Border Community Stations promote the protection of shared regional resources between San Diego and Tijuana. Their evaluation of the U.S.-Mexico border wall as a "self-inflicted environmental wound" (425) sheds a powerful light on concepts like "nature" and "nation" in an era marked by environmental struggles that defy classic hierarchies and century-old narratives of exceptionalism. As such, the essay becomes the inevitable conclusion to an exploration of four centuries of rooting the nation in the "natural."

While the catalog and its bibliography provide a deep dive into all things ecology between the seventeenth and the twenty-first centuries, Braddock and Kusserow further expand the frame in the blog Ecology of an Exhibition on the Princeton Art Museum website. In five sections, readers can explore the ecological components of mounting an exhibition-from the energy consumption of gallery lighting to the carbon footprint of packing, crating, and shipping artworks all the way to ecofriendly paper and ink options to print the catalog (Fig. 5). ${ }^{4}$ 


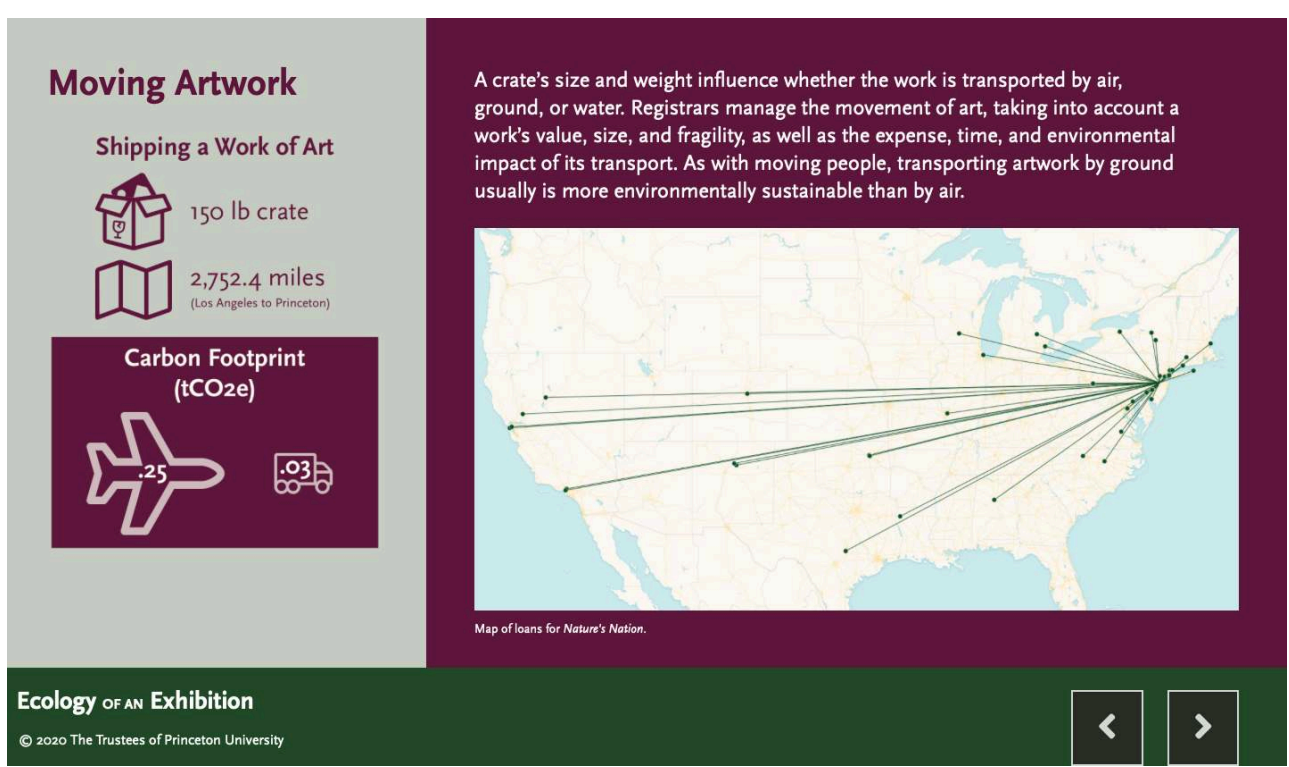

Screenshot from the blog Ecology of an Exhibition: Behind the Scenes of Nature's Nation, Princeton University Art Museum, https://artmuseum.princeton.edu/ecologyofanexhibition/gathering-theobjects/moving-artwork. Retrieved July 13, 2020.

(c) 2020 The Trustees of Princeton University.

Combing the blog with the nineteen essays, Nature's Nation gives us an unprecedented set of tools to think about the environment far beyond art history. Through their exploration of new concepts and re-assessment of artworks, biographies, materials, and itineraries, the authors have created a fruitful terrain for any reader probing their environmental awareness. By taking us "behind the scenes" of the exhibition, Braddock and Kusserow spark new awareness about the environmental dimension of the cultural world at large, asking hands-on questions: What is the ecological footprint of an artwork from San Francisco exhibited at Princeton? Or, how can we choose a more sustainable material for a catalog that will be printed by the tens of thousands? But also, what impact does the artwork have on previous understandings of, say, national parks and their allegedly 'wild' landscapes?

The variety of academic essays, case studies, interviews, and the blog encourages a bold new reading of the environment, its resources and uses, representations and accessfar from the dominant Euro-American settler narrative of a virgin territory. In the future, Nature's Nation could benefit both conceptually and thematically oriented curricula-be they on art history or American studies, minorities, social justice, urban history, geopolitics, the history of animals and food consumption, or material culture. The book's wide-reaching framework certainly inspires us to find new examples to add to this ongoing ecocritical inquiry in a warming, pandemic-ridden twenty-first century. 


\section{BIBLIOGRAPHY}

BRADDOCK, Alan C., and IRMSHER, Christopher. A Keener Perception: Ecocritical Studies of American Art History. Tuscaloosa, University of Alabama Press, 2009.

BRADDOCK, Alan C., and TURNER IGOE, Laura, eds. A Greene Country Towne: Philadelphia's Ecology in the Cultural Imagination. University Park, Pennsylvania State University Press, 2016.

BUELL, Lawrence. The Environmental Imagination: Thoreau, Nature Writing, and the Formation of American Culture. Cambridge, Harvard University Press, 1995.

“Ecology of an Exhibition: Behind the Scenes of Nature's Nation." Princeton University Art Museum, artmuseum.princeton.edu/ecologyofanexhibition.

GLOTFELTY, Cheryll, and FROMM, Harold, eds. The Ecocriticism Reader: Landmarks in Literary Ecology. Athens, University of Georgia, 1996.

KUSSEROW, Karl. Picture Ecology: Art and Ecocriticism in a Planetary Perspective. New Haven, Yale University Press, forthcoming.

MAXWELL, Richard, and MILLER, Toby. Greening the Media. New York, Oxford University Press, 2012.

MORTON, Timothy. The Ecological Thought. Cambridge, Harvard University Press, 2010.

NIXON, Rob. Slow Violence and the Environmentalism of the Poor. Cambridge, Harvard University Press, 2011.

\section{NOTES}

1. See Alan C. Braddock and Christopher Irmsher, eds., A Keener Perception: Ecocritical Studies of American Art History (2009); Braddock and Laura Turner Igoe, eds., A Greene Country Towne: Philadelphia's Ecology in the Cultural Imagination (2016); Karl Kusserow, Picture Ecology: Art and Ecocriticism in a Planetary Perspective (forthcoming).

2. Richard Maxwell and Toby Miller, Greening the Media (2012).

3. Rob Nixon, Slow Violence and the Environmentalism of the Poor (2011).

4. "Ecology of an Exhibition: Behind the Scenes of Nature's Nation," Princeton University Art Museum, https://artmuseum.princeton.edu/ecologyofanexhibition.

\section{INDEX}

Subjects: Recensions 
AUTHORS

CAROLIN GÖRGEN

Associate Professor of American Studies, Sorbonne Université 